\title{
Disturbances of functional parameters of the visual system in conservatively treated and haemodialysed patients with non-diabetic chronic kidney disease
}

\section{Zaburzenia parametrów czynnościowych narządu wzroku u chorych na przewlekłą chorobę nerek o etiologii niecukrzycowej leczonych zachowawczo i poddawanych hemodializie}

\author{
Agnieszka Gajdowska, Piotr Jurowski \\ Department of Ophthalmology and Vision Rehabilitation, Medical University of Lodz, Lodz \\ Head: Professor Piotr Jurowski, MD, PhD
}

Ahstract:

Aim: Chronic kidney disease is becoming a serious problem of public health also because in its initial stage, the disease is latent. Haemodialysotherapy may contribute to negative biochemical processes and also may affect the function of the visual system. The aim of the study was to evaluate changes in functional parameters of the visual system in patients with severe and end-stage chronic kidney disease.

Material and Methods: Depending on the value of estimated glomerular filtration rate (eGFR) and applied therapy, the studied individuals were divided into three groups. Group I: patients with chronic renal failure on haemodialysis (chronic kidney disease, stage 5); Group II: patients with markedly decreased estimated glomerular filtration rate (chronic kidney disease, stage 4); Group III: people with normal estimated glomerular filtration rate. Distance and near best-corrected visual acuity, contrast sensitivity, colour vision, carboxymethyllysine (CML) concentration, lens and macula were examined.

Results: Mean best-corrected distance visual acuity were statistically different $(p=0.000815)$ in Group I and III. Mean near visual acuity was similar in all groups $(p=0.0886)$. Contrast sensitivity differed between Group II and III $(p=0.004895)$. Colour vision differed statistically between study groups $(p=0.027)$. Carboxymethyllysine concentration differed significantly between Groups I and III ( $p=0.001450)$ and between Group II and III ( $p=0.001325)$.

Conclusions: Chronic kidney disease considerably affects the functional state of the visual system. Patients with chronic kidney disease demonstrate impaired contrast sensitivity and colour vision disturbances. Chronic haemodialysis may improve colour vision and, to some extent, parameters regarding contrast sensitivity.

Key words: $\quad$ chronic kidney disease, contrast sensitivity, colour vision, best-corrected visual acuity, carboxymethyllysine.

Ahstrakt: $\quad$ Cel: przewlekła choroba nerek (PChN) staje się coraz poważniejszym problemem zdrowia publicznego. We wczesnych stadiach może mieć przebieg utajony. Przewlekła hemodializoterapia może się przyczyniać do rozwoju niekorzystnych procesów biochemicznych, w tym również wpływać na parametry czynnościowe narządu wzroku. Celem pracy jest ocena zmian w parametrach czynnościowych narządu wzroku u pacjentów chorujących na zaawansowaną i schyłkową przewlekłą chorobę nerek.

Materiał i metody: zależnie od wartości szacowanego współczynnika filtracji kłębuszkowej (eGFR) i stosowanej terapii badane osoby zostały przyporządkowane do trzech grup. Grupa I: hemodializowani chorzy z przewlekłą niewydolnością nerek (stadium 5. przewlekłej choroby nerek), Grupa II: chorzy ze znacznie obniżonym współczynnikiem filtracji kłębuszkowej (stadium 4. przewlekłej choroby nerek), Grupa III: osoby z prawidłowym współczynnikiem filtracji kłębuszkowej. Oceniano najlepszą skorygowaną ostrość wzroku do dali i bliży, poczucie kontrastu oraz widzenie barwne, stężenie karboksymetylolizyny oraz stan soczewki i plamki.

Wyniki: średnia wartość najlepszej skorygowanej ostrości do dali różiła się statystycznie w grupach I i III $(p=0,000815)$. Średnia wartość najlepszej skorygowanej ostrości do bliży była podobna w oczach ze wszystkich grup $(p=0,0886)$. Wyniki badania poczucia kontrastu wykazały różnice w grupach II i III ( $p=0,004895)$. Wyniki badania widzenia barw różniły się statystycznie we wszystkich grupach $(p=0,027)$. Stężenie karboksymetylolizyny różniło się istotnie w grupach I i II $(p=0,001450)$ oraz II i III ( $p=0,001325)$.

Wnioski: przewlekła choroba nerek ma istotny wpływ na stan czynnościowy narządu wzroku. W przypadku tych chorych obserwuje się obniżenie poczucia kontrastu i zaburzenia w rozpoznawaniu barw. Przewlekła hemodializa może wpływać na poprawę wyników widzenia barw i do pewnego stopnia na poczucie kontrastu.

Słowa kluczowe: przewlekła choroba nerek, poczucie kontrastu, widzenie barw, najlepiej skorygowana ostrość wzroku, karboksymetylolizyna. The authors declare no conflict of interest/ Autorzy zgłaszają brak konfliktu interesów w związku z publikowaną pracą 


\section{Introduction}

Chronic kidney disease (CKD) is becoming a serious problem of public health (1). The term refers to a disease syndrome which involves a decrease in the number of active nephrons, which results from various pathological processes, occurring in renal interstitium (2). Glomerular filtration rate which has been lower than $60 \mathrm{~mL} / \mathrm{min} / 1.73 \mathrm{~m}^{2}$ for at least 3 months and results of laboratory tests, confirming renal damage, e.g. albuminuria, are grounds for diagnosing the above disease. In clinical practice, the function of the organ is evaluated on the basis of the estimated glomerular filtration rate (eGFR) (3). It is supposed that 3.2 million patients worldwide are treated due to chronic renal failure. Of that number, 2.25 million are haemodialysed. 272.000 patients are treated with peritoneal dialysis and 678.000 have undergone kidney transplantation (4).

In developed countries, most common causes of CKD include: diabetes, arterial hypertension, glomerulonephritis and autosomal dominant polycystic kidney disease (5). In developing countries, infectious aetiology is dominant (1). In its initial stage, the disease is latent. This latency favours development of multiorgan changes, which mostly results from arterial hypertension, anaemia, dyslipidemia as well as disturbed acid-base, mineral and water-electrolyte balance.

Renal replacement therapy, particularly haemodialysis, substantially affects the quality of patient's life. Thus, the decision on initiating such a therapy is taken for each individual patient. A doctor takes the patient's biochemical parameters into account. However, intensity and severity of disease symptoms are key factors before taking the decision. Abstaining from implementing this therapy could be explained by the fact that haemodialysotherapy may contribute to negative processes, such as dysfunction of endothelial cells of blood vessels or even accelerated atherosclerosis. It is believed that oxidative stress, arising from prolonged catheterization of blood vessels and insufficient biocompatibility of membranes in the filter of the dialysis device, causes those disturbances (6).

Bearing in mind that CKD-related processes and also haemodialysotherapy might affect the function of the visual system $(7,8)$, due to e.g. decreased visual acuity, the authors decided to conduct relevant studies.

\section{Aim}

The aim of the study was to evaluate changes in functional parameters of the visual system in patients with severe and end-stage kidney disease.

\section{Material and Methods}

Chronic kidney disease, documented at least 6 months prior to the ophthalmological examination, was an inclusion criterion.

A particularly important exclusion criterion was diabetes, confirmed with the patient's medical records or diagnosed on the basis of diagnostic criteria, set by the World Health Organization (WHO) (9). Besides, unregulated arterial hypertension and extraocular or intraocular opthalmological procedures, performed at least 6 months prior the study, were other exclusion criteria.

Before implementing the project, the Bioethics Committee of the Medical University of Lodz had given a positive opinion. The research was conducted according to the Declaration of Helsinki. All patients signed a written consent for their participation in the study. Seventy two people (144 eyes) were included in the study.

Depending on the value of estimated glomerular filtration rate (eGFR) and the applied therapy, the studied people were divided into three groups of the same size. Group I consisted of patients with chronic renal failure, treated with haemodialysis (CKD, stage 5); patients with severe CKD stage, with markedly decreased glomerular filtration (CKD, stage 4,) were included in Group II and people with normal glomerular filtration were included in Group III (Tab. I).

In Group I, causes of chronic kidney disease included: unknown factor (6 patients, 25.02\%), chronic glomerulonephritis (5 patients, 20.85\%), nephrolithiasis (4 patients, 16.68\%), polycystic renal degeneration (3 patients, $12.51 \%$ ), hypertensive nephropathy (3 patients, $12.51 \%$ ), toxic drug reaction (1 patient, $4.17 \%)$, chronic interstitial nephritis (1 patient, $4.17 \%$ ) and Wegener's granulomatosis (1 patient, $4.17 \%$ ).

In Group II, causes of chronic kidney disease included: polycystic renal degeneration (7 patients, $29.19 \%)$, chronic glomerulonephritis (6 patients, $25.02 \%$ ), unknown factor (4 patients, $16.68 \%$ ), nephrolithiasis (2 patients, $8.34 \%$ ), hypertensive nephropathy (1 patient, $4.17 \%$ ), toxic drug reaction (1 patient, $4.17 \%)$, unilateral renal hypoplasia and contralateral nephrectomy (1 patient, $4.17 \%$ ), after trauma (1 patient, $4.17 \%$ ) and Ormond's syndrome (1 patient, $4.17 \%$ ).

Respondents from Group III, not affected by the above disease, made regular medical appointments due to: nephrolithiasis (15 people, 62.55\%), recurrent urinary tract infections (6 people, $25.02 \%$ ) and single renal cysts (3 people, $12.51 \%$ ).

The analysis of best-corrected visual acuity (BCVA) was preceded by spherocylindrical correction for distance and near

\begin{tabular}{|c|c|c|c|}
\hline & Group I/ Grupa I & Group II/ Grupa II & Group III/ Grupa III \\
\hline Mean eGFR $-\left[\mathrm{mL} / \mathrm{min} / 1.73 \mathrm{~m}^{2}\right]$ / Średnie eGFR & $6.48 \pm 2.25$ & $15.38 \pm 8.05$ & $80.92 \pm 13.48$ \\
\hline Number [of individuals]/ Liczba osób & 24 & 24 & 24 \\
\hline Females/ Kobiety & 12 & 12 & 14 \\
\hline Males/ Mężczyźni & 12 & 12 & 10 \\
\hline Mean age [years]/ Średni wiek [lata] & $64.42 \pm 12.81$ & $66.58 \pm 11.93$ & $64.17 \pm 11.82$ \\
\hline Glycaemia [mmol/L]/ Glikemia & $5.17 \pm 0.40$ & $4.84 \pm 0.58$ & $5.04 \pm 0.48$ \\
\hline
\end{tabular}

Tab. I. Characteristics of the study groups.

Tab. I. Charakterystyka badanych grup. 
vision, and conducted with the application of an examination technique, prepared by Regan and Boeder and modified by Habela (10). The analysis was carried out using Snellen optotypes for distance and near visual acuity assessment. The value was 0.001 if, during the best-corrected distance visual acuity assessment, the patient reported only light perception. If the patient could see hand movements in front of his/her eye, the recorded value was 0.005 . If he/she was able to count fingers from a distance of 1 meter, the value was 0.01 . In the event of lack of light perception, the score was 0 . For a patient who was not able to make out the biggest optotypes for near vision but his/ her distance visual acuity was at least equal to light perception, the result of the best-corrected near visual acuity assessment was identified as $3.5 / 30 \mathrm{~cm}$.

Due to poor health of many participants of the study, the authors used the Pelli-Robson contrast sensitivity chart in order to assess the patients' contrast sensitivity and Farnsworth 15 Hue test to evaluate colour vision. The authors used these tests since they were easy to apply and reliable. Besides, they allowed for conducting a further statistical analysis. Each eye was tested separately with the application of the best correction. In the Pelli-Robson test the authors recorded the last triplet, of which at least two elements were identified correctly. Then, they recorded the value which corresponded to the triplet on the chart. As for colour vision, it was identified as:

- normal - all hue tiles were arranged in a correct sequence,

- mildly disturbed - hue tiles were incorrectly arranged in not more than three positions,
- single-axis disturbances - the course of the sequence corresponded to the main confusion axis of colour vision: red (protan), green (deutan) or blue (tritan),

- severely disturbed - the line connecting tiles numbers did not correspond to any of the above sequences; a lot of tiles were incorrectly arranged, which implied multi-axis disturbances.

Slit lamp examination was performed to evaluate crystalline lens and macula. Blood sample was obtained from every person in order to measure serum carboxymethyllysine (CML) concentration with ELISA test (EIAab, Wuhan, China). CML belongs to large group of advanced glycation-end products (AGE) which are observed to accumulate in CKD patients (11).

The authors used the Kruskal-Wallis test and chi-square test. The Dunn's test was used in order to analyse relationships among the studied groups.

\section{Results}

Mean best-corrected distance visual acuity values were statistically different ( $p=0.000815$ ) between Group I and Group III. Mean values for the above groups were (V for visus): $\mathrm{V}_{1}=0.56 \pm 0.30$ (median 0.63), $\mathrm{V}_{\|}=0.66 \pm 0.30$ (median 0.73 ) and $V_{I I I}=0.78 \pm 0.22$ (median 0.8). Mean near visual acuity was similar in all groups $(p=0.0886)$ (tab. II).

Spherical refractive error ranged from $-2.0 \mathrm{D}$ to $+8.0 \mathrm{D}$ in Group I, from $-3.75 \mathrm{D}$ to $+8.0 \mathrm{D}$ in Group II and from $-7.0 \mathrm{D}$ to $+5.0 \mathrm{D}$ in Group III while maximal cylindrical refractive error was $-3.5,-3.75$ and -3.25 , respectively.

\begin{tabular}{|c|c|c|c|c|c|c|}
\hline \multirow[b]{2}{*}{$\begin{array}{l}\text { Distance vision/near vision/ } \\
\text { Ostrość wzroku do dali/ bliży }\end{array}$} & \multicolumn{2}{|c|}{ Group I/ Grupa I } & \multicolumn{2}{|c|}{ Group II/ Grupa II } & \multicolumn{2}{|c|}{ Group III/ Grupa III } \\
\hline & $\begin{array}{c}\text { distance vision/ } \\
\text { dal }\end{array}$ & $\begin{array}{l}\text { near vision/ } \\
\text { bliz }\end{array}$ & $\begin{array}{l}\text { distance vision/ } \\
\text { dal }\end{array}$ & $\begin{array}{l}\text { near vision/ } \\
\text { bliz }\end{array}$ & $\begin{array}{l}\text { distance vision/ } \\
\text { dal }\end{array}$ & $\begin{array}{l}\text { near vision/ } \\
\text { bliż }\end{array}$ \\
\hline $\begin{array}{l}\text { Number of tested eyes/ } \\
\text { Liczba badanych oczu }\end{array}$ & 48 & 48 & 48 & 48 & 48 & 48 \\
\hline Minimum/ Minimum & 0.001 & 3.50 & 0.01 & 3.50 & 0.20 & 2.00 \\
\hline Maximum/ Maksimum & 1.00 & 0.50 & 1.25 & 0.50 & 1.00 & 0.50 \\
\hline Median/ Mediana & 0.63 & 0.50 & 0.73 & 0.50 & 0.80 & 0.50 \\
\hline Arithmetic mean/ Średnia arytmetyczna & 0.56 & 0.98 & 0.66 & 0.77 & 0.78 & 0.58 \\
\hline Standard deviation/ Odchylenie standardowe & 0.30 & 0.95 & 0.30 & 0.71 & 0.22 & 0.24 \\
\hline Statistical analysis/ Analiza statystyczna & \multicolumn{6}{|c|}{$\begin{array}{c}\text { distance/ dal: Kruskal-Wallis: } \mathrm{H}(2, N=144)=13.62815 \mathbf{p}=\mathbf{0 . 0 0 1 1} \text { near/ bliż: Kruskal-Wallis: } \\
\qquad \mathrm{H}(2, N=144)=4.846383 \mathrm{p}=0.0886\end{array}$} \\
\hline $\begin{array}{l}\text { Multiple group comparison/ } \\
\text { Porównanie wielokrotne grup } \\
\text { Distance vision/ Dal }\end{array}$ & \multicolumn{6}{|c|}{ Dunn $p=$} \\
\hline Group I/ Grupa I & & & $\begin{array}{c}1.460710 \\
p=0.43229\end{array}$ & & $\begin{array}{c}3.640765 \\
p=0.00082\end{array}$ & \\
\hline Group II/ Grupa II & $\begin{array}{c}1.460710 \\
p=0.43229\end{array}$ & & & & $\begin{array}{c}2.180055 \\
p=0.08776\end{array}$ & \\
\hline Group III/ Grupa III & $\begin{array}{c}3.640765 \\
p=0.00082\end{array}$ & & $\begin{array}{c}2.180055 \\
p=0.08776\end{array}$ & & & \\
\hline
\end{tabular}

Tab. II. Best-corrected distance and near visual acuity results in study groups.

Tab. II. Wyniki badania najlepszej skorygowanej ostrości wzroku do dali i bliży w badanych grupach. 
No light perception as well as hand movements in front of patient's eye were not observed in studied groups. The lowest recorded value of distance visual acuity was 0.001 in Group I for a patient with advanced cataract. Counting fingers from a distance of 1 meter recorded as 0.01 was present in one patient from Group I with history of uveitis and in one patient from Group II due to previous corneal graft. Poor near visual outcome identified as $3.5 / 30 \mathrm{~cm}$ was present in afore mentioned patients and also in case of bilateral central retinal vein occlusion (Group I) and in strabismus amblyopia (Group II).

The analysis confirmed a statistically significant difference ( $p=0.004895$ ) in contrast sensitivity in Group II and Group III. The authors did not observe any statistically significant differences between groups: I and II ( $p=0.412490)$ or groups: I and III $(p=0.287730)$ (tab. III).

An analysis of colour vision confirmed a statistically significant difference between study groups $(p=0.027)$. Group
I most often demonstrated mild disturbances (16 eyes, 33.33\%) and single-axis disturbances (14 eyes, 29.17\%). Severe, multi-axis disturbances were noted in this group in 5 eyes (10.42\%). Patients from Group II were usually affected by mild colour vision disturbances (14 eyes, 29.17\%); less frequently did they have severe colour vision anomalies (12 eyes, $25 \%$ ). Single-axis anomalies were noted in 9 eyes $(18.75 \%)$. Farnsworth 15 Hue test, performed in Group III, revealed mild colour vision disturbances in as many as 25 eyes $(52.08 \%)$; single-axis anomalies were observed in 7 eyes $(14.58 \%)$ and severe disturbances were noted in 4 eyes (8.33\%) (tab. IV).

Crystalline lens transparency was significantly different between groups $(p=0.0031)$. Cortical or nuclear cataract was observed more frequently in group I (19 eyes, $39.58 \%)$, less frequently in group II, (7 eyes, $14.58 \%)$ whereas the rarest it was in group III (5 eyes, 10.42\%). Percent of initial opacification of the lens was in groups I,II and III as follows: $47.92 \%$

\begin{tabular}{|c|c|c|c|}
\hline & Group I/ Grupa I & Group II/ Grupa II & Group III/ Grupa III \\
\hline Number of tested eyes/ Liczba badanych oczu & 48 & 48 & 48 \\
\hline Minimum/ Minimum & 0.00 & 0.00 & 0.90 \\
\hline Maximum/ Maksimum & 1.65 & 1.65 & 1.65 \\
\hline Median/ Mediana & 1.35 & 1.20 & 1.35 \\
\hline Arithmetic mean/ Średnia arytmetyczna & 1.17 & 1.13 & 1.35 \\
\hline Standard deviation/ Odchylenie standardowe & 0.44 & 0.38 & 0.22 \\
\hline Statistical analysis/ Analiza statystyczna & \multicolumn{3}{|c|}{ Kruskal-Wallis: $\mathrm{H}(2, \mathrm{~N}=144)=10.40692 \mathrm{p}=0.0055$} \\
\hline Multiple group comparison/ Porównanie wielokrotne grup & \multicolumn{3}{|c|}{ Dunn $p=$} \\
\hline Group I/ Grupa I & & $\begin{array}{c}1.485178 \\
p=0.412490\end{array}$ & $\begin{array}{c}1.665014 \\
p=0.287730\end{array}$ \\
\hline Group II/ Grupa II & $\begin{array}{c}1.485178 \\
p=0.412490\end{array}$ & & $\begin{array}{c}3.150192 \\
p=0.004895\end{array}$ \\
\hline Group III/ Grupa III & $\begin{array}{c}1.665014 \\
p=0.287730\end{array}$ & $\begin{array}{c}3.150192 \\
p=0.004895\end{array}$ & \\
\hline
\end{tabular}

Tab. III. Contrast sensitivity results in study groups.

Tab. III. Wyniki poczucia kontrastu w badanych grupach.

\begin{tabular}{|c|c|c|c|c|c|c|}
\hline & \multicolumn{2}{|c|}{ Group I/ Grupa I } & \multicolumn{2}{|c|}{ Group II/ Grupa II } & \multicolumn{2}{|c|}{ Group III/ Grupa III } \\
\hline & $\begin{array}{l}\text { number of eyes/ } \\
\text { liczba oczu }\end{array}$ & $\%$ & $\begin{array}{l}\text { number of eyes/ } \\
\text { liczba oczu }\end{array}$ & $\%$ & $\begin{array}{l}\text { number of eyes/ } \\
\text { liczba oczu }\end{array}$ & $\%$ \\
\hline Test not performed/ Nie wykonano badania & 5 & 10.42 & 3 & 6.25 & 0 & 0.00 \\
\hline Normal/ Prawidłowe & 8 & 16.67 & 10 & 20.83 & 12 & 25.00 \\
\hline Mildly disturbed/ Łagodnie zaburzone & 16 & 33.33 & 14 & 29.17 & 25 & 52.08 \\
\hline Single-axis/ Jednoosiowe & 14 & 29.17 & 9 & 18.75 & 7 & 14.58 \\
\hline Severely disturbed/ Głęboko zaburzone & 5 & 10.42 & 12 & 25.00 & 4 & 8.33 \\
\hline In total/ Razem & 48 & 100.00 & 48 & 100.00 & 48 & 100.00 \\
\hline Statistical analysis/ Analiza statystyczna & \multicolumn{6}{|c|}{ chi $^{2}$ Pearson $=17.32 \mathbf{p}=\mathbf{0 . 0 2 7}$ chi $^{2}{ }_{N w}=19.02 \mathbf{p}=\mathbf{0 . 0 1 4 7}$} \\
\hline
\end{tabular}

Tab. IV. Colour vision results in the study groups.

Tab. IV. Wyniki testu widzenia barwnego w badanych grupach. 
(23 eyes), $58.33 \%$ (28 eyes) and $66.67 \%$ (32 eyes), respectively. Cataract surgery was performed mainly in patients in group II (11 eyes, 22.92\%) and group III (9 eyes, 18.75\%), rarely in group I ( 2 eyes, $4.17 \%$ ) (Tab. V).

Analysis of macular changes showed significant differences only in occurrence of dry age-related macular degeneration (AMD) between examined groups $(p=0.008)$. The most often it was observed in group III (18 eyes, $37.50 \%$ ), rarely in group II (10 eyes, 20.83\%), uncommonly in group I (4 eyes, $9.30 \%$ ). Because of very rare appearance of wet AMD, epiretinal membranes, and other changes in macula, they were not included in statistical analysis.

Analysis of CML concentration revealed significant differences between groups I and III $(p=0.001450)$ and also II and III $(p=0.001325)$, with mean values as follows: $9.76 \pm 3.43 \mathrm{ng} / \mathrm{mL}$, median $8.31 \mathrm{ng} / \mathrm{mL}$ (group I), $11.11 \pm 5.49 \mathrm{ng} / \mathrm{mL}$, median $9.24 \mathrm{ng} / \mathrm{mL}$ (group II) and $6.65 \pm 2.06 \mathrm{ng} / \mathrm{mL}$, median $6.43 \mathrm{ng} / \mathrm{mL}$ (group III) (Tab. VI).

\section{Discussion}

Despite relatively low mean distance visual acuity in the haemodialysed patients, only two of them (8.33\%) met criteria for severely decreased visual acuity, according to standards set forth by WHO - H 54.1 in ICD-10 (12). In contrast to the above results, we can mention a study conducted by Chiu et al., who observed that $39 \%$ of patients met criteria for classifying them as legally blind (7). The age of the studied patients $(64.42$ \pm 12.81 years vs. $74.9 \pm 6.1$ years) as well as the size of the groups (24 patients vs. 159 patients) might have contributed to such huge differences. Differences regarding the aetiology of CKD are striking. The authors of this study excluded diabetic patients, whereas in the study carried out by Chiu et al., patients with diabetes made up almost half the studied population. Bearing in mind the above observations, it should be pointed out that diabetics demonstrate microangiopathy not only in kidneys but also in the visual system, which can be mildly or severely affected by the disease (13). A study by El-Asrar perfectly

\begin{tabular}{|c|c|c|c|c|c|c|}
\hline & \multicolumn{2}{|c|}{ Group I/ Grupa I } & \multicolumn{2}{|c|}{ Group II/ Grupa II } & \multicolumn{2}{|c|}{ Group III/ Grupa III } \\
\hline & $\begin{array}{l}\text { number of eyes/ } \\
\text { liczba oczu }\end{array}$ & $\%$ & $\begin{array}{l}\text { number of eyes/ } \\
\text { liczba oczu }\end{array}$ & $\%$ & $\begin{array}{l}\text { number of eyes/ } \\
\text { liczba oczu }\end{array}$ & $\%$ \\
\hline Transparent/ Przezierna & 4 & 8.33 & 2 & 4.17 & 2 & 4.17 \\
\hline Initial opacification/ Początkowe zmętnienia & 23 & 47.92 & 28 & 58.33 & 32 & 66.67 \\
\hline Cortical or nuclear cataract/ Zaćma jądrowa lub korowa & 19 & 39.58 & 7 & 14.58 & 5 & 10.42 \\
\hline Intraocular lens/ Rzekomosoczewkowość & 2 & 4.17 & 11 & 22.92 & 9 & 18.75 \\
\hline In total/ Razem & 48 & 100.00 & 48 & 100.00 & 48 & 100.00 \\
\hline Satistical analysis/ Analiza statystyczna & \multicolumn{6}{|c|}{$\operatorname{chi}^{2}{ }_{\text {Pearson }}=19.66 \mathbf{p}=\mathbf{0 . 0 0 3 1 9} \mathrm{chi}^{2}{ }_{\mathrm{Nw}}=20.27 \mathbf{p}=\mathbf{0 . 0 0 2 4 8}$} \\
\hline
\end{tabular}

Tab. V. Crystalline lens transparency assessment in the study groups.

Tab. V. Ocena przezierności soczewki w badanych grupach.

\begin{tabular}{|c|c|c|c|}
\hline & Group I/ Grupa I & Group II/ Grupa II & Group III/ Grupa III \\
\hline Number of tested person/ Liczba badanych osób & 24 & 24 & 24 \\
\hline Minimum/ Minimum & 5.70 & 4.92 & 2.47 \\
\hline Maximum/ Maksimum & 20.08 & 24.14 & 12.25 \\
\hline Median/ Mediana & 8.31 & 9.24 & 6.43 \\
\hline Arithmetic mean/ Średnia arytmetyczna & 9.76 & 11.11 & 6.65 \\
\hline Standard deviation/ Odchylenie standardowe & 3.43 & 5.49 & 2.06 \\
\hline Statistical analysis/ Analiza statystyczna & \multicolumn{3}{|c|}{ Kruskal-Wallis: $\mathrm{H}(2, \mathrm{~N}=72)=7.813142 \mathrm{p}=0.0201$} \\
\hline Multiple group comparison/ Porównanie wielokrotne grup & \multicolumn{3}{|c|}{ Dunn $p=$} \\
\hline Group I/ Grupa I & & $\begin{array}{c}0.024139 \\
p=1.000000\end{array}$ & $\begin{array}{c}3.489738 \\
p=0.001450\end{array}$ \\
\hline Group II/ Grupa II & $\begin{array}{c}0.024139 \\
p=1.000000\end{array}$ & & $\begin{array}{c}3.513877 \\
p=0.001325\end{array}$ \\
\hline Group III/ Grupa III & $\begin{array}{c}3.489738 \\
p=0.001450\end{array}$ & $\begin{array}{c}3.513877 \\
p=0.001325\end{array}$ & \\
\hline
\end{tabular}

Tab. VI. Results of CML blood serum concentration test in the study groups.

Tab. VI. Wyniki badania stężenia CML w surowicy krwi w badanych grupach. 
exemplifies this observation. The author noted that $45.5-50 \%$ patients with proliferative diabetic retinopathy are also affected by concomitant diabetic nephropathy (14). Other researchers, Yoshimoto and Matsumoto, observed that as many as $21 \%$ of patients who started to be treated with haemodialysis, demonstrated decreased visual acuity (15). The above study results as well as the authors' own observations and clinical experience confirm a considerable impact of diabetes on the function of the visual system, including visual acuity in CKD patients. In our study, proper criteria, excluding diabetics from the stu$d y$, allowed us to create a homogenous, well selected group of patients. It should also be emphasized that currently in professional literature there are no reports on evaluation of changes in visual parameters in conservatively treated and chronically haemodialysed non-diabetic CKD patients. An analysis of prevalence of cataract, conducted in the study groups, might help to identify the source of potential causes of functional changes. It was observed in 19 eyes in patients from Group I, in 7 eyes in Group II, and in 5 eyes in Group III. The authors revealed that higher cataract prevalence corresponded to lowered mean visual acuity. 22 eyes in total udergone cataract extraction but unfortunately no data on implanted intraocular lens type were available.

The authors noted that patients with advanced CKD (Group II) demonstrated, in comparison to the other groups, the lowest mean contrast sensitivity. Its value was statistically different from the group with normal renal function. Professional literature does not contain comparative analyses on contrast sensitivity and colour vision in patients with CKD, stages 4 and 5 . Woo et al. noted an improvement in contrast sensitivity after one dialysis session in patients with end stage of CKD (8). Chiu et al. evaluated functional changes in the visual system in old-age haemodialysed patients and made an interesting observation (7). Results of the study imply that a high percentage of patients is affected with lowered contrast sensitivity $(37 \%)$.

The authors of this study did not confirm a statistical difference with regards to contrast sensitivity in patients with advanced and end stage of CKD (Group I and Group II). However, its mean value was slightly higher in haemodialysed patients. Moreover, patients with advanced stage of CKD (Group II) demonstrated severe multi-axis colour vision disturbances and the prevalence was statistically significant. What is interesting, such disturbances occurred 2.5 times less frequently in haemodialysed patients. With regards to subjects from Group III, visual disturbances were observed less often and they were less severe. Thus, it can be concluded that CKD has a negative impact on the function of the visual system. Results obtained by Woo et al. (8) imply that dialysis therapy has a positive effect on contrast sensitivity and colour vision, which might result from the fact that during a dialysis session, uraemic toxins are partly but regularly removed from the body.

The influence of CKD on the visual system is related to dysfunction of neural cells. Some researchers point out a negative impact of electrolyte disturbances on neural activity and mention hyperkalaemia $(16,17)$ and hypermagnesaemia $(18)$, but it should be underlined that none of these concerned visual pathway neurons. However, some study teams question this relationship (19). While seeking causes of negative changes, occurring in CKD patients, scientists tried to draw attention to a heterogenous group of compounds, i.e. advanced glycation end-products (AGEs). The authors determined the level of $\mathrm{N}^{\varepsilon}$-(carboxymethyl)lysine (CML), which is one of best known AGEs. Its level was significantly higher in patients with CKD (Group I and Group II) in comparison to subjects with normal renal function. Since there are reports on a negative impact of AGE on peripheral neural cells $(20,21)$, it could be concluded that the relationship observed by the authors of this study, reflects to some extent the mentioned impact. Besides, a slight, yet a noticeable difference in CML levels in the studied groups of CKD patients, treated conservatively and chronically haemodialysed, implies a beneficial effect of a renal replacement therapy, contributing to a decrease in the AGE level in the circulation. Further studies incorporating other diagnostic tools such as for instance electrophysiology might help to elucidate and perhaps confirm our observations.

\section{Conclusions}

Chronic kidney disease considerably affects the functional state of the visual system. Patients with CKD demonstrate impaired contrast sensitivity and colour vision disturbances. Chronic haemodialysis may improve colour vision.

\section{References:}

1. Jha V, Garcia-Garcia G, Iseki K, Li Z, Naicker S, Plattner B, et al.: Chronic kidney disease: global dimension and perspectives. The Lancet. 2013; 382(9888): 260-272.

2. Król E, Rutkowski B: Przewlekła choroba nerek - klasyfikacja, epidemiologia i diagnostyka. Forum Nefrol. 2008; 1(1): 1-6.

3. Levin A, Stevens PE, Bilous RW, Coresh J, De Francisco ALM, De Jong PE, et al.: Kidney Disease: Improving Global Outcomes (KDIGO) CKD Work Group: KDIGO 2012 clinical practice guideline for the evaluation and management of chronic kidney disease. Kidney Int Suppl. 2013; 3(1): e150.

4. Fresenius Medical Care Deutschland GmbH. ESRD patients in 2013. A global perspective. [Internet]. 2013. Dostępne na: http://www.vision-fmc.com/files/ESRD_Patients_in_2013.pdf

5. Himmelfarb J, Sayegh MH: Chronic Kidney Disease, Dialysis, and Transplantation: A Companion to Brenner and Rector's The Kidney. Elsevier Health Sciences; 2010.

6. Himmelfarb J, Stenvinkel P, Ikizler TA, Hakim RM: The elephant in uremia: oxidant stress as a unifying concept of cardiovascular disease in uremia. Kidney Int. 2002; 62(5): 1524-1538.

7. Chiu E, Markowitz SN, Cook WL, Jassal SV: Visual impairment in elderly patients receiving long-term hemodialysis. Am J Kidney Dis. 2008; 52(6): 1131-1138.

8. Woo GC, Mandelman T, Liu TT, Haberstroh BA: Effect of hemodialysis on contrast sensitivity in renal failure. Optom Vis Sci. 1986; 63(5): 356-361.

9. Organization $\mathrm{WH}$, others. Definition and diagnosis of diabetes mellitus and intermediate hyperglycaemia: report of a WHO. 2006 [cytowane 13 październik 2016]; dostępne na: http:// apps.who.int/iris/handle/10665/43588

10. Habela M: Podstawowe zasady badania refrakcji metodą subiektywną. Kontaktologia i Optyka Okulistyczna. 2002; 5(1): 30-32. 
11. Thornalley PJ: Glycation free adduct accumulation in renal disease: the new AGE. Pediatr Nephrol. 2005; (20): 1515-1522.

12. ICD-10 Version:2015 [Internet]. [cytowane 24 październik 2016]. Dostępne na: http://apps.who.int/classifications/icd10/ browse/2015/en

13. Pearce I, Simó R, Lövestam AM, Wong DT, Evans M: Association between diabetic eye disease and other complications of diabetes: Implications for care. A systematic review. Diabetes, Obesity and Metabolism. ..... ROK; Tom, STRONY

14. El-Asrar AMA, Al-Rubeaan KA, Al-Amro SA, Moharram OA, Kangave D: Retinopathy as a predictor of other diabetic complications. Int Ophthalmol. 2001; 24(1): 1-11.

15. Yoshimoto M, Matsumoto S: Changes in diabetic retinopathy and visual acuity in patients with end-stage diabetic nephropathy after the introduction of hemodialysis. Nippon Ganka Gakkai Zasshi. 2006; 110(4): 271-275.

16. Krishnan AV, Phoon RKS, Pussell BA, Charlesworth JA, Kiernan MC: Sensory nerve excitability and neuropathy in end stage kidney disease. J Neurol Neurosurg Psychiatry. 2006; 77(4): 548-551.
17. Krishnan AV, Phoon RK, Pussell BA, Charlesworth JA, Bostock $\mathrm{H}$, Kiernan MC: Altered motor nerve excitability in end-stage kidney disease. Brain. 2005; 128(9): 2164-2174.

18. Fleming LW, Lenman JAR, Stewart WK: Effect of magnesium on nerve conduction velocity during regular dialysis treatment. J Neurol Neurosurg Psychiatry. 1972; 35(3): 342-355.

19. Lim JH, Kim IT: The electroretinogram in chronic renal failure. Korean J Ophthalmol. 1998; 12(1): 68-72.

20. Sugimoto K, Yasujima M, Yagihashi S: Role of advanced glycation end products in diabetic neuropathy. Curr Pharm Des. 2008; 14(10): 953-961.

21. Jack M, Wright D: Role of advanced glycation endproducts and glyoxalase I in diabetic peripheral sensory neuropathy. Transl Res. 2012; 159(5): 355-365.

The paper was originally received 24.06.2018 (K0-00168-2018)/ Praca wpłynęła do Redakcji 24.06.2018 r. (KO-00168-2018)

Accepted for publication 17.02.2019/

Zakwalifikowano do druku 17.02.2019 r.

Reprint requests to (Adres do korespondencji): lek. Agnieszka Gajdowska Klinika Okulistyki i Rehabilitacji Wzrokowej USK im. WAM ul. Żeromskiego 113, 90-549 Łódź e-mail: agnieszkajgajdowska@gmail.com 